\title{
Grain yield and termite damage in rice by compaction on the furrow and seed treatment
}

\author{
Veneraldo Pinheiro(1), Luís Fernando Stone(1), \\ José Alexandre Freitas Barrigossi ${ }^{(1)}$ and Adriano Stephan Nascente ${ }^{(1)}$
}

(1)Embrapa Arroz e Feijão, Rodovia GO-462, Km 12, Fazenda Capivara, Zona Rural, Caixa Postal 179, CEP 75375-000 Santo Antônio de Goiás, GO, Brazil. E-mail: venaldo.pinheiro@embrapa.br, luis.stone@embrapa.br, jose.barrigossi@embrapa.br, adriano.nascente@embrapa.br

\begin{abstract}
The objective of this work was to determine the effects of soil compaction pressure on the sowing furrow and of seed treatments with insecticides on grain yield and on termite damage in upland rice plants under no-tillage, in the Center West region of Brazil. Three experiments were carried out, consisting of five seed treatments combined with three (first experiment) or four (second and third experiments) compaction pressures in a randomized complete block design, in a factorial arrangement. The seed treatments were: T0, without treatment; T1, imidacloprid+thiodicarb; T2, thiamethoxam; T3, carbofuran; and T4, fipronil $+p$ yraclostrobin+thiophanate-methyl. The compaction pressures applied were: 25,42 , and $268 \mathrm{kPa}$, in the first experiment; and these same pressures plus $126 \mathrm{kPa}$ in the second and third experiments. Seed treatment was effective in increasing rice grain yield, from 1,753 to $4,141 \mathrm{~kg} \mathrm{ha}^{-1}$, especially in the lowest compaction pressure of $25 \mathrm{kPa}$. Soil compaction around $180 \mathrm{kPa}$ in the sowing furrow results in higher rice grain yield and in fewer stems killed by termites. The use of soil compaction on the sowing furrow with seed treatment significantly increases rice grain yield under a no-tillage system.
\end{abstract}

Index terms: Oryza sativa, compaction pressure, insecticides, no-tillage.

\section{Produtividade e danos por cupins em arroz com a compactação no sulco e o tratamento de sementes}

Resumo - O objetivo deste trabalho foi determinar os efeitos da pressão de compactação do solo no sulco de semeadura e dos tratamentos de sementes com inseticidas sobre a produtividade de grãos e sobre os danos causados por cupins nas plantas de arroz de terras altas, em plantio direto, na região Centro-Oeste do Brasil. Foram realizados três experimentos, que consistiram de cinco tratamentos de sementes combinados com três (primeiro experimento) ou quatro (segundo e terceiro experimentos) pressões de compactação em delineamento de blocos ao acaso, em arranjo fatorial. Os tratamentos de sementes foram: T0, sem tratamento; T1, imidacloprid+thiodicarb; T2, thiametoxam; T3, carbofuran; e T4, fipronil+pyraclostrobin+tiofanato metílico. As pressões de compactação aplicadas foram: 25, 42 e $268 \mathrm{kPa}$, no primeiro experimento; e essas mesmas pressões mais $126 \mathrm{kPa}$, no segundo e no terceiro experimentos. O tratamento de sementes foi eficaz no aumento da produção de grãos de arroz, de 1.753 para $4.141 \mathrm{~kg} \mathrm{ha}^{-1}$, especialmente na pressão de compactação mais baixa, de $25 \mathrm{kPa}$. A pressão de compactação de aproximadamente $180 \mathrm{kPa}$ no sulco de semeadura proporciona maior rendimento de grãos de arroz e menos colmos mortos por cupins. O uso da compactação do solo na linha de semeadura com tratamento de sementes aumenta significativamente a produtividade de grãos de arroz no sistema plantio direto.

Termos para indexação: Oryza sativa, pressão de compactação, inseticidas, plantio direto.

\section{Introduction}

Rice is a grain included in the diet of half of the world's population, and this cereal is mostly grown under irrigation (Prasad, 2011). Growing rice under a no-tillage system (NTS) is an alternative to produce this crop in aerobic conditions (Nascente et al., 2013). According to Nokkoul \& Wichitparp (2014), an area of approximately 20 million hectares is cultivated with upland rice, mainly in Latin America and Africa. The NTS, due to the benefits provided to the environment, such as greater conservation of water and increased soil fertility, organic matter content, and protection of the soil against erosion, had a significant global growth. The five countries with the largest areas under 
this system are the United States, Brazil, Argentina, Canada, and Australia, with 35.6, 31.8, 29.2, 18.3, and 17.7 million hectares, respectively (FAO, 2015).

However, under a NTS, upland rice crops have not had a good development (Nascente et al., 2011). In this system, the $0.00-0.05-\mathrm{m}$ soil layer usually shows high porosity, which is attributed to the following factors: action of the seeder discs; highest concentration of roots and organic matter; greater biological activity; and more cycles of soil wetting and drying (Collares et al., 2006; Reichert et al., 2009), which can hinder the contact of the rice seed with the soil, reducing plant emergence.

In this context, the compaction on the sowing furrow performed by the seeder press wheel improves ground contact with the seeds, allowing them to absorb water earlier and to germinate faster (Modolo et al., 2007). This practice increases upland rice grain yield under no-tillage (Pinheiro et al., 2016a, 2016b).

Termites, such as Procornitermes araujoi, $P$. triacifer, and Syntermes molestus, occur in most upland rice fields established on soils in the Cerrado (Brazilian savanna), causing significant losses in crop grain yield, and are also the main reason insecticides are used to treat seeds before sowing (Ferreira et al., 2007). Under a NTS, the problem is compounded because of the straw accumulation on soil surface, increasing food availability for termites, which can cause total losses in rice production (Barbosa et al., 2009). In addition, in this system, there is no reduction in the population of these insects by exposure, crushing, and destruction of galleries, as done in conventional tillage (plowing once and harrowing twice).

Chemical control of termites has been the most widely used and the most effective control method (Verma et al., 2009). However, the detrimental effect of insecticides on the environment cannot be ignored. An alternative to the use of insecticides is soil compaction on the sowing furrow. Ferreira et al. (2007) reported that the termite attack on upland rice grown under notillage was lower with soil compaction on the sowing furrow, in comparison with no compaction, and that the benefit of this practice was reinforced when combined with seed treatment with insecticides.

Despite the importance of the study of soil compaction on the sowing furrow for rice development and the reduction of termite attack, there is still little scientific evidence on this subject.
The objective of this work was to determine the effects of soil compaction pressure on the sowing furrow and of seed treatments with insecticides on grain yield and on termite damage in upland rice plants under no-tillage, in the Center West region of Brazil.

\section{Materials and Methods}

The experimental area was located in the municipality of Santo Antônio de Goiás, in the state of Goiás, in the Center West region of Brazil (16 $27^{\circ} 28^{\prime \prime S}$, $49^{\circ} 19^{\prime} 52^{\prime \prime} \mathrm{W}$, at $823 \mathrm{~m}$ above sea level). The climate is a tropical savanna, Aw according to Köppen's classification. There are two distinct seasons, usually dry from May to September and rainy from October to April, with average annual rainfall of $1,485 \mathrm{~mm}$. During the experiment, temperature and rainfall data were recorded (Figure 1).

The soil was classified as a Latossolo Vermelho argiloso (Typic Haplorthox) (Santos et al., 2006). Soil texture in the $0.00-0.20-\mathrm{m}$ layer showed: 271 $\mathrm{g} \mathrm{kg}^{-1}$ sand, $100 \mathrm{~g} \mathrm{~kg}^{-1}$ silt, and $629 \mathrm{~g} \mathrm{~kg}^{-1}$ clay. Before the application of the treatments, the chemical characteristics of the soil were determined according to the methods described by Claessen (1997). The obtained results were: $\mathrm{pH}\left(\mathrm{H}_{2} \mathrm{O}\right) 5.7 ; 16 \mathrm{mmol}_{\mathrm{c}} \mathrm{kg}^{-1} \mathrm{Ca}^{2+}$; $7 \mathrm{mmol}_{\mathrm{c}} \mathrm{kg}^{-1} \mathrm{Mg}^{2+} ; 1 \mathrm{mmol}_{\mathrm{c}} \mathrm{kg}^{-1} \mathrm{Al}^{3+} ; 50$ mmol $_{\mathrm{c}} \mathrm{kg}^{-1}$ $\mathrm{H}^{+}+\mathrm{Al}^{3+}$; $3.2 \mathrm{mg} \mathrm{kg}^{-1} \mathrm{P} ; 101 \mathrm{mg} \mathrm{kg}^{-1} \mathrm{~K}^{+} ; 2.6 \mathrm{mg} \mathrm{kg}^{-1} \mathrm{Cu}^{2+}$; $2.2 \mathrm{mg} \mathrm{kg}^{-1} \mathrm{Zn}^{2+} ; 33 \mathrm{mg} \mathrm{kg}^{-1} \mathrm{Fe}^{3+} ; 26 \mathrm{mg} \mathrm{kg}^{-1} \mathrm{Mn}^{2+}$; and $26.4 \mathrm{~g} \mathrm{~kg}^{-1}$ soil organic matter.

Three experiments were carried out with upland rice crop under no-tillage. In the first one, rice was sown on January 27, 2011, on desiccated straw of Urochloa brizantha, after nine years of pasture. The second experiment was sown in another area, on December 8, 2011, on desiccated rice straw from the previous year, whereas the third experiment was sown on January 24, 2013, on the desiccated straw of the second experiment.

The experiments were conducted in a randomized complete block design, in a factorial arrangement, with three replicates, and consisted of five seed treatments combined with three (first experiment) or four (second and third experiments) soil compaction pressures on the sowing furrow (CP). Based on the results of the first experiment, it was decided to increase the soil compaction pressures to obtain more information. The seed treatments were: T1, imidacloprid+thiodicarb, $52.5+157.5 \mathrm{~mL}$ a.i. per $100 \mathrm{~kg}$ seed; T2, thiamethoxam, 

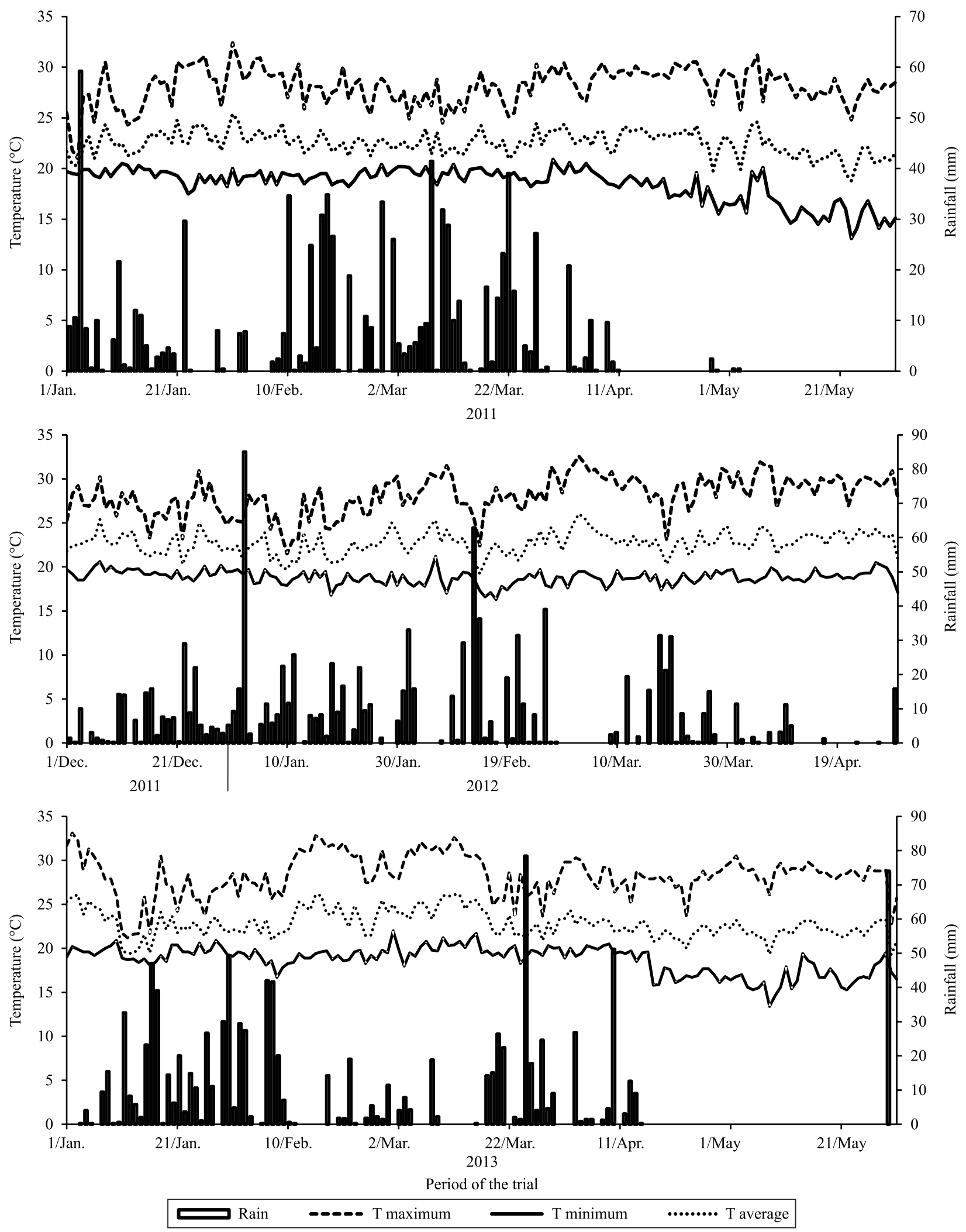

Figure 1. Maximum, minimum, and average temperatures $(\mathrm{T})$, and rainfall recorded in the experimental field during the experimental period. 
140 g a.i. per $100 \mathrm{~kg}$ seed; T3, carbofuran, $527 \mathrm{~mL}$ a.i. per $100 \mathrm{~kg}$ seed; and T4, fipronil+pyraclostrobin +thiophanate-methyl, $62.5+0.625+50.625 \mathrm{~mL}$ a.i. per $100 \mathrm{~kg}$ seed. All treatments were compared with a control (T0) without seed treatment. The soil compaction pressures applied in the first experiment were: $25 \mathrm{kPa}$, provided by the original "V" press wheel of the seed drill; $42 \mathrm{kPa}$, provided by the mass of $96.6 \mathrm{~kg}$ of a wheel adapted in the seed drill; and $268 \mathrm{kPa}$, provided by the mass of $635 \mathrm{~kg}$ on the front axle of a MF $52754 \times 2$ tractor (Massey Ferguson, AGCO, Duluth, GA, EUA) with 7.50-16 F2 directional vehicular tires with three treads (smaller contact area and high pressure on the ground). These same CP were applied in the second and third experiments plus the pressure of $126 \mathrm{kPa}$, provided by the mass of $635 \mathrm{~kg}$ on the front axle of the same tractor with 7.50-16 bald directional vehicular tires (no slots, larger contact area, and reduced pressure on the ground). The compaction pressures were estimated based on the weight of the wheels or tractor and on the contact area of the wheels or tires with the ground.

The first experiment was conducted in $20 \times 2.25-\mathrm{m}$ plots, with the upland rice cultivar BRS Pepita, spaced at $0.45 \mathrm{~m}$, with 200 seeds per square meter. Sowing was performed with a seed drill, model Personale Drill 13, (Semeato S/A Implementos Agrícolas, Passo Fundo, RS, Brazil), with a system known as "guillotine knife coulter", and sowing fertilization was done with $17 \mathrm{~kg} \mathrm{ha}^{-1} \mathrm{~N}$ as urea, $102 \mathrm{~kg} \mathrm{ha}^{-1} \mathrm{P}_{2} \mathrm{O}_{5}$ as triple superphosphate, and $51 \mathrm{~kg} \mathrm{ha}^{-1} \mathrm{~K}_{2} \mathrm{O}$ as potassium chloride. Nitrogen topdressing fertilizations with urea were done at $1\left(60 \mathrm{~kg} \mathrm{ha}^{-1}\right), 17\left(32 \mathrm{~kg} \mathrm{ha}^{-1}\right)$, and 43 $\left(26 \mathrm{~kg} \mathrm{ha}^{-1}\right)$ days after rice emergence.

The second experiment was conducted in $10 \times 2.25-\mathrm{m}$ plots, with the same cultivar. Sowing was done with the same seed drill, and sowing fertilization was also performed with $17 \mathrm{~kg} \mathrm{ha}^{-1} \mathrm{~N}$ as urea, $102 \mathrm{~kg} \mathrm{ha}^{-1}$ $\mathrm{P}_{2} \mathrm{O}_{5}$ as triple superphosphate, and $51 \mathrm{~kg} \mathrm{ha}^{-1} \mathrm{~K}_{2} \mathrm{O}$ as potassium chloride. Nitrogen topdressing fertilizations as urea $\left(42 \mathrm{~kg} \mathrm{ha}^{-1}\right)$ were performed at 18 and 35 days after rice emergence.

The third experiment was carried out on the same plots as the second one, with the same cultivar, seed drill, and sowing fertilization. Nitrogen topdressing fertilizations as urea were done at $1\left(20 \mathrm{~kg} \mathrm{ha}^{-1}\right), 20\left(40 \mathrm{~kg} \mathrm{ha}^{-1}\right)$, and $28\left(28 \mathrm{~kg} \mathrm{ha}^{-1}\right)$ days after rice emergence.
In all trials, the same tillage practices were applied to keep the area free from weeds, diseases, and insects. Moreover, the usable area of the plot was composed of three central rows of rice, disregarding $0.50 \mathrm{~m}$ on each side.

In the second and third experiments, the soil resistance to vertical penetration (PR) was determined through a penetrograph, penetroLOG-PLG 1020 model, (Falker, Porto Alegre, RS, Brazil) at the $0.00-0.20$-m depth, at three points in each plot, one in each useful line. The data were obtained in $\mathrm{kPa}$, and average values of PR were calculated for the $0.05-\mathrm{m}$ layers until the $0.20-\mathrm{m}$ depth. Sampling was performed one day after rain, with soil moisture close to field capacity. The data was presented as the cone index to the depth of $0.20 \mathrm{~m}$, considering the mean value of cone penetration resistance.

Rice harvesting was done after physiological maturity, with cutting by hand in the usable area in each plot. Plots were assessed regarding grain yield, which was determined by weighing the harvested grain of each plot, corrected to $13 \%$ of water content and converted to $\mathrm{kg} \mathrm{ha}^{-1}$. In all experiments, the number of stems killed by termites in $1 \mathrm{~m}$ of row (SK), in three predetermined points on the centerlines of the plots, was evaluated throughout the crop season.

Data were subjected to analysis of variance using the Sisvar statistical software (Universidade Federal de Lavras, Lavras, MG, Brazil), and means were compared by Tukey's test, at 5\% probability. Regression analysis was also performed to determine the effects of CP and SK on grain yield.

\section{Results and Discussion}

A significant effect was observed on seed treatment $\mathrm{x}$ compaction pressures, in terms of rice grain yield in the first experiment (Table 1). In the other experiments, there was a significant single effect of seed treatment and of compaction pressures on grain yield. Regarding stems killed by termites, the effect of seed treatment was significant only in the first experiment, whereas the effect of compaction pressures was significant in the second and third ones.

The increase in grain yield with seed treatment with insecticides, when compared with the untreated ones, is probably due to the reduction in crop damage by soil insects. Ferreira et al. (2007) found that seed 
treatment with insecticides reduced plant mortality caused by termites and the lesser cornstalk borer (Elasmopalpus lignosellus), increasing grain yield. Pinheiro et al. (2016b) also reported that seed treatment provided greater control of termites in upland rice crop than no treatment. However, Ferreira et al. (2007) pointed out that the insecticide carbofuran, although effective in the control of sucking insects that attack rice in the early stages of plant development, had low efficiency in controlling termites. This is an indicative

Table 1. P-values of the $\mathrm{F}$ tests for source of variation of upland rice grain yield (GY) and number of stems killed by termites in $1 \mathrm{~m}$ of row (SK) in the three experiments carried out.

\begin{tabular}{lccccccccc}
\hline Source of & \multicolumn{2}{c}{$1^{\text {st }}$ experiment } & & \multicolumn{2}{c}{$2^{\text {nd }}$ experiment } & & \multicolumn{2}{c}{$3^{\text {rd }}$ experiment } \\
\cline { 2 - 3 } variation & GY & SK & & GY & SK & & GY & SK \\
\hline ST & $<0.001$ & $<0.001$ & & 0.002 & ${ }^{\text {ns }}$ & & 0.043 & ns \\
CP & $<0.001$ & ns & & $<0.001$ & $<0.001$ & & $<0.001$ & $<0.001$ \\
ST x CP & 0.035 & ns & & ns & ns & & ns & ns \\
\hline
\end{tabular}

${ }^{\mathrm{ns}}$ Nonsignificant at $5 \%$ probability. ST, seed treatment; $\mathrm{CP}$, compaction pressure.

Table 2. Upland rice grain yield $\left(\mathrm{kg} \mathrm{ha}^{-1}\right)$ affected by seed treatment and compaction pressure on the sowing furrow, in the first experiment ${ }^{(1)}$.

\begin{tabular}{lccc}
\hline \multirow{2}{*}{$\begin{array}{l}\text { Seed } \\
\text { treatment }\end{array}$} & \multicolumn{3}{c}{ Compaction pressure on sowing furrow $(\mathrm{kPa})$} \\
\cline { 2 - 4 } T0 & 25 & 42 & 268 \\
$\mathrm{~T} 1$ & $1,753 \mathrm{~b}$ & $3,046 \mathrm{~b}$ & $4,117 \mathrm{a}$ \\
$\mathrm{T} 2$ & $4,141 \mathrm{a}$ & $4,417 \mathrm{a}$ & $4,694 \mathrm{a}$ \\
$\mathrm{T} 3$ & $3,056 \mathrm{a}$ & $3,501 \mathrm{ab}$ & $5,104 \mathrm{a}$ \\
$\mathrm{T} 4$ & $3,323 \mathrm{a}$ & $3,736 \mathrm{ab}$ & $4,774 \mathrm{a}$ \\
\hline
\end{tabular}

(1)Means followed by equal letters, in the columns, do not differ by Tukey's test, at $5 \%$ probability. T0, without seed treatment; T1, imidacloprid+thiodicarb, $52.5+157.5 \mathrm{~mL}$ a.i. per $100 \mathrm{~kg}$ seed; T2, thiamethoxam, $140 \mathrm{~g}$ a.i. per $100 \mathrm{~kg}$ seed; T3, carbofuran, $527 \mathrm{~mL}$ a.i. per $100 \mathrm{~kg}$ seed; and T4, fipronil+pyraclostrobin+thiophanate-methyl, $62.5+$ $0.625+50.625 \mathrm{~mL}$ a.i. per $100 \mathrm{~kg}$ seed. that differences regarding grain yield among seed treatments with insecticides are probably due to their effect on termites.

In the first experiment, at the lowest compaction pressure of $25 \mathrm{kPa}$, the $\mathrm{T} 0$ treatment had the lowest grain yield and differed from all the other ones (Table 2); however, there was no significant difference among the other seed treatments. At the compaction pressure of $42 \mathrm{kPa}$, the T1 and T4 treatments provided the highest grain yield, differing from $\mathrm{T} 0$ but not from the other seed treatments. At the highest compaction pressure of $268 \mathrm{kPa}$, there was no effect of seed treatment on grain yield. It should be noted that the absence of seed treatment favored higher termite damage, resulting in a greater number of stems killed, which differed from treatments T1, T3, and T4 (Table 3) and affected negatively grain yield (Figure 2). In T1, T3, and $\mathrm{T} 4$, there was no significant effect of compaction pressures on grain yield; however, under the T0 and T2 treatments, grain yield increased linearly with compaction pressures (Table 4).

In the second experiment, the lowest grain yield was obtained in T0 $\left(2,158 \mathrm{~kg} \mathrm{ha}^{-1}\right)$, which differed from the other treatments (Table 3). The only exception was T3, which showed similar results to T0. In the third experiment, grain yield in the T0 treatment was significantly lower than that obtained in T4. Although the number of stems killed was greater in absolute values in the second and third experiments under $\mathrm{T} 0$, there was no significant difference among seed treatments regarding this variable (Table 3). The increase in the number of killed stems could be explained by the fact that the second and third experiments were performed after the rice crop, which is a known preferable food for termites (Ferreira et al., 2007).

The lower grain yield in $\mathrm{T} 0$, at lower compaction pressures, may be due to the increased mortality of plants

Table 3. Upland rice grain yield and number of stems killed by termites in $1 \mathrm{~m}$ of row affected by seed treatment ${ }^{(1)}$.

\begin{tabular}{|c|c|c|c|c|c|}
\hline \multirow{2}{*}{$\begin{array}{l}\text { Seed } \\
\text { treatment }\end{array}$} & \multicolumn{2}{|c|}{ Grain yield $\left(\mathrm{kg} \mathrm{ha}^{-1}\right)$} & \multicolumn{3}{|c|}{ Stems killed by termites (number) } \\
\hline & $2^{\text {nd }}$ experiment & $3^{\text {rd }}$ experiment & $1^{\text {st }}$ experiment & $2^{\text {nd }}$ experiment & $3^{\text {rd }}$ experiment \\
\hline T0 & $2,158 b$ & $611 \mathrm{~b}$ & $10.3 \mathrm{a}$ & $14.5 \mathrm{a}$ & $33.7 \mathrm{a}$ \\
\hline $\mathrm{T} 1$ & $3,375 \mathrm{a}$ & $1,082 \mathrm{ab}$ & $0.3 \mathrm{c}$ & $6.3 \mathrm{a}$ & $27.9 \mathrm{a}$ \\
\hline $\mathrm{T} 2$ & $3,084 \mathrm{a}$ & $956 \mathrm{ab}$ & $3.1 \mathrm{ab}$ & $10.3 \mathrm{a}$ & $29.3 \mathrm{a}$ \\
\hline $\mathrm{T} 3$ & $3,007 \mathrm{ab}$ & $984 \mathrm{ab}$ & $1.4 \mathrm{bc}$ & $10.9 \mathrm{a}$ & $22.9 \mathrm{a}$ \\
\hline $\mathrm{T} 4$ & $3,366 \mathrm{a}$ & $1,251 \mathrm{a}$ & $0.7 \mathrm{c}$ & $4.6 \mathrm{a}$ & $30.6 \mathrm{a}$ \\
\hline
\end{tabular}

(1) Means followed by equal letters, in the columns, do not differ by Tukey's test, at $5 \%$ probability. T0, without seed treatment; T1, imidacloprid + thiodicarb, $52.5+157.5 \mathrm{~mL}$ a.i. per $100 \mathrm{~kg}$ seed; T2, thiamethoxam, $140 \mathrm{~g}$ a.i. per $100 \mathrm{~kg}$ seed; T3, carbofuran, $527 \mathrm{~mL}$ a.i. per $100 \mathrm{~kg}$ seed; and T4, fipronil+pyraclostrobin+thiophanate-methyl, $62.5+0.625+50.625 \mathrm{~mL}$ a.i. per $100 \mathrm{~kg}$ seed. 
caused by soil insects, especially termites, as reported by Ferreira et al. (2007) and Pinheiro et al. (2016b). The increase in compaction pressures contributes to control termites (Pinheiro et al., 2016a) and is possibly why, in general, there were no differences among seed treatments at higher compaction pressures. According to Radford \& Allsopp (1987), soil compaction over the rice rows may: squash large insect pests near the seed, killing or injuring them; restrict the movement of insects through the soil; improve soil water supply, enabling seedlings to escape pest damage by faster germination and growth; or reduce carbon dioxide diffusion from the seed/seedling, by reducing soil porosity - it should be highlighted that carbon dioxide attracts several species of wireworm.

In the second and third experiments, grain yield showed a quadratic response increase to compaction pressures (Table 5), with the maximum values being reached with the soil pressures of 181.6 and $177.9 \mathrm{kPa}$, respectively. The number of stems killed also showed a quadratic response to compaction pressures, but with minimum values of 195.7 and $186.2 \mathrm{kPa}$, respectively.

The effect of compaction pressures on grain yield depends on the intensity of the load applied. Modolo et al. (2007) found that low loads on the sowing furrow decreased the contact between the soil and the seed by limiting the amount of water that reaches seed surface, reducing plant emergence; however, high loads can

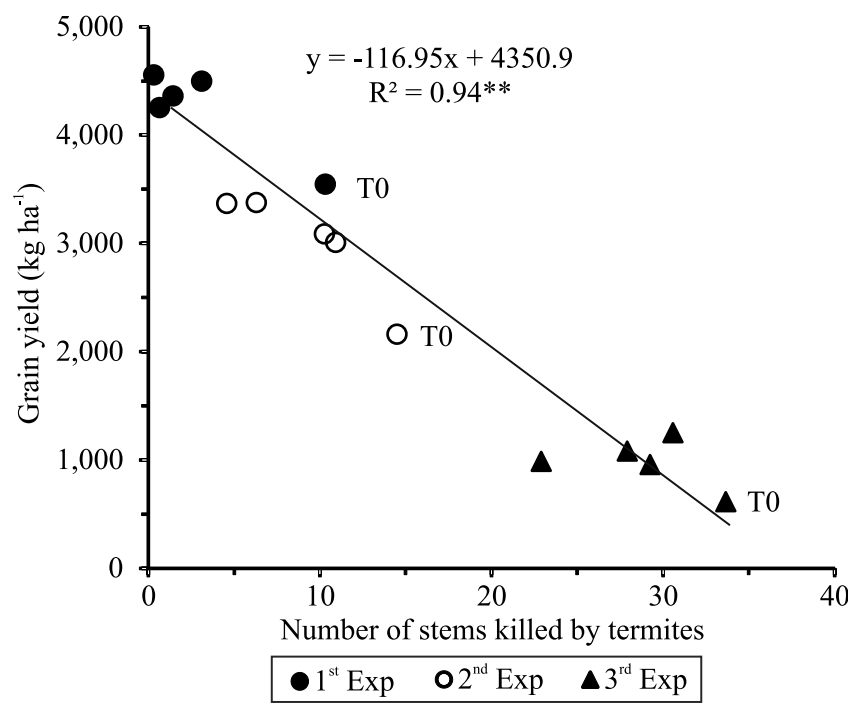

Figure 2. Upland rice grain yield as a function of number of stems killed by termites in $1 \mathrm{~m}$ of row. $1^{\text {st }}$ Exp, $2^{\text {nd }}$ Exp, and $3^{\text {rd }}$ Exp, first, second, and third experiments carried out. T0, without seed treatment. cause surface crusting, reducing the penetration of oxygen, so that the plant needs to consume more energy to emerge. Pinheiro et al. (2016a) also evaluated upland rice under no-tillage and reported a favorable effect of compaction pressures on grain yield.

Since the third experiment was conducted on the straw of the second one, it can be concluded that the continuous cultivation of rice in the same area increased damage by termites and reduced grain yield (Table 3 and Figure 2). This lower grain yield in the third experiment, in comparison with the second one, is in alignment with the results obtained by several other authors, who do not recommend the continuous cultivation of upland rice in the same area due to the sharp fall in productivity (Fageria \& Baligar, 2003; Nie et al., 2009; Godoy et al., 2013). This decline in grain yield has been attributed to allelopathic effects (Fageria \& Baligar, 2003), which

Table 4. Regression equation for grain yield (GY) as a function of compaction pressure on the sowing furrow (CP), in the first experiment.

\begin{tabular}{lll}
\hline Seed treatment & \multicolumn{1}{c}{ Equation $^{(1)}$} & \multicolumn{1}{c}{$\mathrm{R}^{2}$} \\
\hline T0 & $\mathrm{GY}=1,873.5+9.53 \mathrm{CP}$ & $0.55^{* *}$ \\
T1 & $\mathrm{GY}=4,213.0+1.83 \mathrm{CP}$ & $0.08^{\text {ns }}$ \\
T2 & $\mathrm{GY}=3,009.5+7.86 \mathrm{CP}$ & $0.60^{*}$ \\
T3 & $\mathrm{GY}=3,343.7+5.38 \mathrm{CP}$ & $0.34^{\text {ns }}$ \\
T4 & $\mathrm{GY}=3,370.7+3.84 \mathrm{CP}$ & $0.17^{\text {ns }}$ \\
\hline
\end{tabular}

(1)Regression analysis performed with nine pairs of data, except for T0, with 12 pairs, because the combination $\mathrm{T} 0 \times 25 \mathrm{kPa}$ was repeated six times. T0, without seed treatment; T1, imidacloprid+thiodicarb, $52.5+157.5 \mathrm{~mL}$ a.i. per $100 \mathrm{~kg}$ seed; T2, thiamethoxam, $140 \mathrm{~g}$ a.i. per $100 \mathrm{~kg}$ seed; T3, carbofuran, $527 \mathrm{~mL}$ a.i. per $100 \mathrm{~kg}$ seed; and T4, fipronil+pyraclostrobin+ thiophanate-methyl, $62.5+0.625+50.625 \mathrm{~mL}$ a.i. per $100 \mathrm{~kg}$ seed.

Table 5. Regression equations for grain yield (GY) and number of stems killed by termites in $1 \mathrm{~m}$ of row (SK) as a function of compaction pressure on the sowing furrow (CP), in the second and third experiments $(\mathrm{n}=60)$.

\begin{tabular}{lcc}
\hline Equation & $\mathrm{R}^{2}$ & $\begin{array}{c}\text { Maximum } / \text { minimum } \\
\mathrm{X}(\mathrm{kPa})\end{array}$ \\
\hline \multicolumn{3}{c}{$2^{\text {nd }}$ experiment } \\
$\mathrm{GY}=-0.0844 \mathrm{CP}^{2}+30.66 \mathrm{CP}+1388.3$ & $0.39^{* *}$ & 181.6 \\
$\mathrm{SK}=0.0009 \mathrm{CP}^{2}-0.3522 \mathrm{CP}+28.0$ & $0.53^{* *}$ & 195.7 \\
\multicolumn{3}{c}{$3^{\text {rd }}$ experiment } \\
$\mathrm{GY}=-0.0461 \mathrm{CP}^{2}+16.40 \mathrm{CP}+124.5$ & $0.41^{* *}$ & 177.9 \\
$\mathrm{SK}=0.002 \mathrm{CP}^{2}-0.7446 \mathrm{CP}+69.4$ & $0.69^{* *}$ & 186.2 \\
\hline
\end{tabular}

(1) T0, without seed treatment; T1, imidacloprid+thiodicarb, $52.5+157.5 \mathrm{~mL}$ a.i. per $100 \mathrm{~kg}$ seed; T2, thiamethoxam, $140 \mathrm{~g}$ a.i. per $100 \mathrm{~kg}$ seed; T3, carbofuran, $527 \mathrm{~mL}$ a.i. per $100 \mathrm{~kg}$ seed; and T4, fipronil+pyraclostrobin+ thiophanate-methyl, $62.5+0.625+50.625 \mathrm{~mL}$ a.i. per $100 \mathrm{~kg}$ seed. 
are any direct or indirect harmful effects of a plant on another one through the production of chemical compounds released into the environment.

The greater accumulation of exudates released by rice plants and the larger number of glyphosate applications in the area of the second rice crop may have altered the activity and the composition of the microbial community, contributing to the lower rice grain yield, as observed by Godoy et al. (2013). Furthermore, the continuous cultivation of rice increased termite infestation in the area, also increasing the number of dead stems and reflecting in grain yield drop, as found in the present work.

Penetration resistance increased gradually from the surface to the 0.20 -m depth with increasing compaction
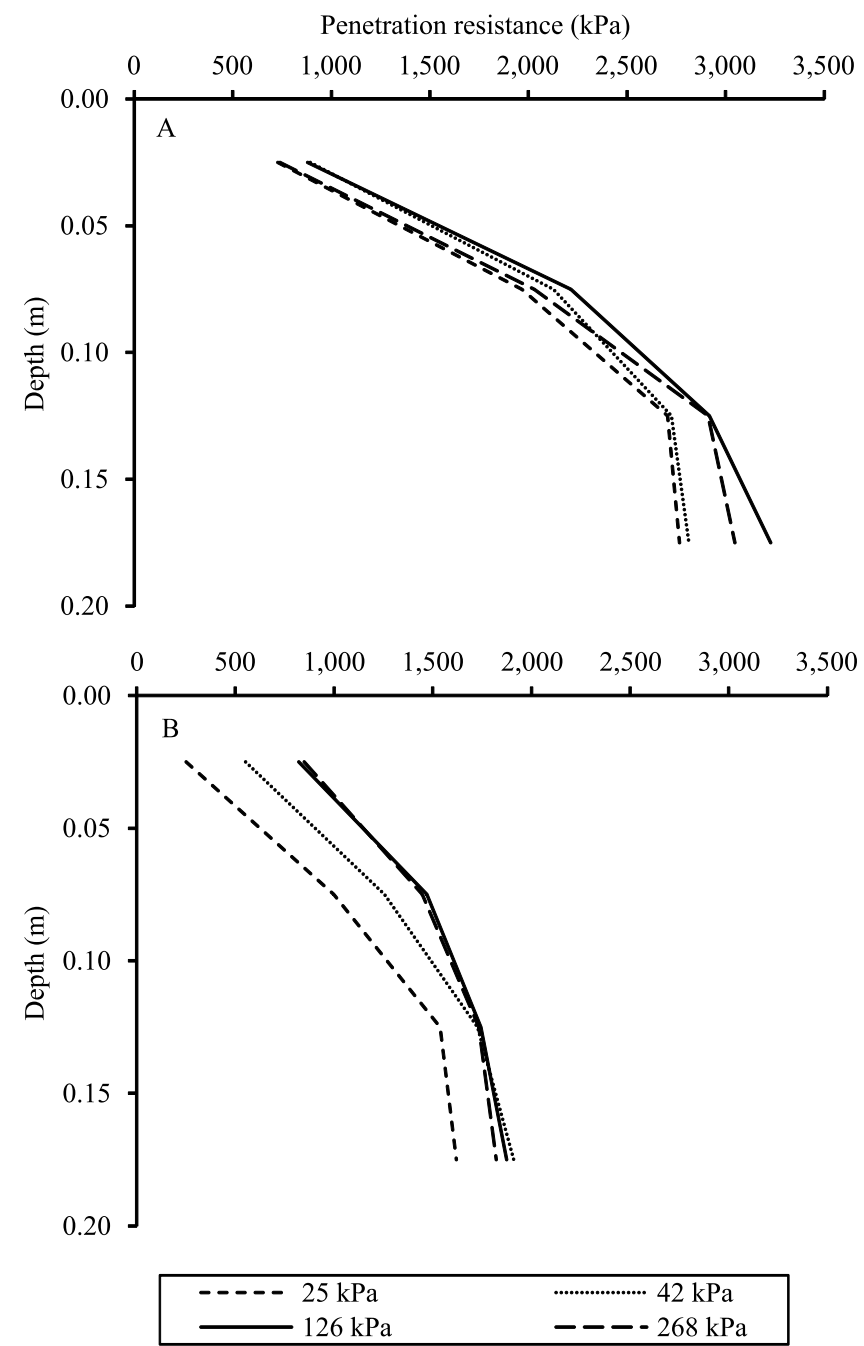

Figure 3. Penetration resistance as a function of compaction pressure on the sowing furrow, in the second (A) and third experiments (B). pressures (Figure 3). In the second experiment, the penetration resistance value reached around $3,200 \mathrm{kPa}$ at the two higher compaction pressures studied. For these same pressures and for $42 \mathrm{kPa}$, the value of penetration resistance was around $1,850 \mathrm{kPa}$ in the third experiment.

The increase in penetration resistance with the increase in depth is probably due to the lack of soil disturbance and the presence of machinery traffic, as also reported by Cunha et al. (2011). However, the increase in penetration resistance with increasing compaction pressures must not have damaged the rice crop, since the penetration resistance values that limit root growth and crop yield were close to $3,000 \mathrm{kPa}$ (Reinert et al., 2008). Moreover, according to Tormena et al. (2007), this value can reach $3,500 \mathrm{kPa}$ in soil cultivated under long-term no-tillage, justified by the presence of continuous and effective biopores. Therefore, according to the obtained results, it can be inferred that the use of soil compaction on the sowing furrow can contribute to increase rice grain yield without damaging rice root development.

\section{Conclusions}

1. Seed treatment is effective in increasing upland rice grain yield, from 1,753 to $4,141 \mathrm{~kg} \mathrm{ha}^{-1}$, especially in the lowest compaction pressure of $25 \mathrm{kPa}$.

2. Soil compaction around $180 \mathrm{kPa}$ on the sowing furrow results in higher rice grain yield and fewer stems killed by termites.

\section{References}

BARBOSA, L.H.A.; MATA, W.M.; FERREIRA, E.P.B.; DIDONET, A.D. Produtividade do arroz de terras altas após o cultivo de plantas de cobertura no Cerrado goiano. Revista Brasileira de Agroecologia, v.4, p.200-203, 2009.

CLAESSEN, M.E.C. (Org.). Manual de métodos para análise de solo. 2.ed. rev. e atual. Rio de Janeiro: EMBRAPA-CNPS, 1997. 212p. (EMBRAPA-CNPS. Documentos, 1).

COLLARES, G.L.; REINERT, D.J.; REICHERT, J.M.; KAISER, D.R. Qualidade física do solo na produtividade da cultura do feijoeiro num Argissolo. Pesquisa Agropecuária Brasileira, v.41, p.1663-1674, 2006. DOI: 10.1590/S0100-204X2006001100013.

CUNHA, E. de Q.; STONE, L.F.; MOREIRA, J.A.A.; FERREIRA, E.P. de B.; DIDONET, A.D.; LEANDRO, W.M. Sistema de preparo do solo e culturas de cobertura na produção orgânica de feijão e milho. I - atributos físicos do solo. Revista Brasileira de Ciência do Solo, v.35, p.589-602, 2011. DOI: 10.1590/S010006832011000200028 . 
FAGERIA, N.K.; BALIGAR, V.C. Upland rice and allelopathy. Communications in Soil Science and Plant Analysis, v.34, p.1311-1329, 2003. DOI: 10.1081/CSS-120020447.

FAO. Food and Agriculture Organization of the United Nations. Aquastat. Available at: <http://www.fao.org/nr/water/aquastat/ data>. Accessed on: Nov. 292015.

FERREIRA, E.; BARRIGOSSI, J.A.F.; SILVA, J.G. da; STONE, L.F.; MOREIRA, J.A.A. Fatores influenciando o ataque de cupim rizófago em plantio direto de arroz de terras altas. Pesquisa Agropecuária Tropical, v.37, p.176-181, 2007.

GODOY, S.G. de; STONE, L.F.; FERREIRA, E.P. de B.; COBUCCI, T.; LACERDA, M.C. Atributos físicos, químicos e biológicos do solo impactado por cultivos sucessivos de arroz. Revista Brasileira de Engenharia Agrícola e Ambiental, v.17, p.1278-1285, 2013. DOI: 10.1590/S1415-43662013001200005.

MODOLO, A.J.; FERNANDES, H.C.; SCHAEFER, C.E.G.; SANTOS, N.T.; SILVEIRA, J.C.M. da. Efeito do teor de água do solo e da carga aplicada pela roda compactadora na velocidade de emergência da soja. Acta Scientiarum. Agronomy, v.29, p.587-592, 2007. Suplemento especial. DOI: 10.4025/actasciagron.v29i5.713.

NASCENTE, A.S.; CRUSCIOL, C.A.C.; COBUCCI, T. The notillage system and cover crops - alternatives to increase upland rice yields. European Journal of Agronomy, v.45, p.124-131, 2013. DOI: 10.1016/j.eja.2012.09.004.

NASCENTE, A.S.; KLUTHCOUSKI, J.; RABELO, R.R.; OLIVEIRA, P. de O.; COBUCCI, T.; CRUSCIOL, C.A.C. Desenvolvimento e produtividade de cultivares de arroz de terras altas em função do manejo do solo. Pesquisa Agropecuária Tropical, v.41, p.186-192, 2011. DOI: 10.5216/pat.v41i2.6980.

NIE, L.; XIANG, J.; PENG, S.; BOUMAN, B.A.M.; HUANG, J.; CUI, K.; VISPERAS, R.M. Alleviating soil sickness caused by aerobic monocropping: responses of aerobic rice to fallow, flooding and crop rotation. Journal of Food, Agriculture and Environment, v.7, p.723-727, 2009.

NOKKOUL, R.; WICHITPARP, T. Effect of drought condition on growth, yield and grain quality of upland rice. American Journal of Agricultural and Biological Sciences, v.9, p.439-444, 2014. DOI: 10.3844/ajabssp.2014.439.444.

PINHEIRO, V.; NASCENTE, A.S.; STONE, L.F.; LACERDA, M.C. Seed treatment, soil compaction and nitrogen management affect upland rice. Pesquisa Agropecuária Tropical, v.46, p.7279, 2016b. DOI: 10.1590/1983-40632016v4638428.

PINHEIRO, V.; STONE, L.F.; BARRIGOSSI, J.A.F. Rice grain yield as affected by subsoiling, compaction on sowing furrow and seed treatment. Revista Brasileira de Engenharia Agrícola e Ambiental, v.20, p.395-400, 2016a. DOI: 10.1590/1807-1929/ agriambi.v20n5p395-400.

PRASAD, R. Aerobic rice systems. In: SPARKS, D.L. Advances in agronomy. Amsterdam: Elsevier, 2011. v.111, p.207-236. DOI: 10.1016/B978-0-12-387689-8.00003-5.

RADFORD, B.J.; ALLSOPP, P.G. Use of insecticides and a press wheel to control soil insects affecting sorghum and sunflower establishment in southern Queensland. Australian Journal of Entomology, v.26, p.161-167, 1987. DOI: 10.1111/j.14406055.1987.tb00279.x.

REICHERT, J.M.; KAISER, D.R.; REINERT, D.J.; RIQUELME, U.F.B. Variação temporal de propriedades físicas do solo e crescimento radicular de feijoeiro em quatro sistemas de manejo. Pesquisa Agropecuária Brasileira, v.44, p.310-319, 2009. DOI: 10.1590/S0100-204X2009000300013.

REINERT, D.J.; ALBUQUERQUE, J.A.; REICHERT, J.M.; AITA, C.; ANDRADA, M.M.C. Limites críticos de densidade do solo para o crescimento de raízes de plantas de cobertura em Argissolo Vermelho. Revista Brasileira de Ciência do Solo, v.32, p.1805-1816, 2008. DOI: 10.1590/S010006832008000500002 .

SANTOS, H.G. dos; JACOMINE, P.K.T.; ANJOS, L.H.C. dos; OLIVEIRA, V.A. de; OLIVEIRA, J.B. de; COELHO, M.R.; LUMBRERAS, J.F.; CUNHA, T.J.F. (Ed.). Sistema brasileiro de classificação de solos. 2.ed. Rio de Janeiro: Embrapa Solos, 2006. 306p.

TORMENA, C.A.; ARAÚJO, M.A.; FIDALSKI, J.; COSTA, J.M. da. Variação temporal do intervalo hídrico ótimo de um Latossolo Vermelho distroférrico sob sistemas de plantio direto. Revista Brasileira de Ciência do Solo, v.31, p.211-219, 2007. DOI: 10.1590/S0100-06832007000200003.

VERMA, M.; SHARMA, S.; PRASAD, R. Biological alternatives for termite control: a review. International Biodeterioration and Biodegradation, v.63, p.959-972, 2009. DOI: 10.1016/j. ibiod.2009.05.009.

Received on February 1, 2015 and accepted on June 6, 2016

Pesq. agropec. bras., Brasília, v.51, n.11 p.1813-1820, nov. 2016

DOI: 10.1590/S0100-204X2016001100003 